\title{
Economic Burden of Malaria for Households in the Municipality of Kouand é and in the Control and Municipality of Copargo in Benin
}

\section{Charles P Makoutodé ${ }^{1 *}$, Martine Audibert ${ }^{2}$ and Achille Massougbodji ${ }^{3}$}

${ }^{1}$ Doctoral School Multidisciplinary Space Culture and Development, University of Abomey Calavi, 01 BP 526, Cotonou, Benin

${ }^{2}$ Centre for Studies and Research on International Development, CNRS, 65 Boulevard Francois Mitterrand, 63000 Clermont-Ferrand, France

${ }^{3}$ Faculty of Health Sciences of Cotonou, University of Abomey Calavi, 01BP188, Cotonou, Benin

"Corresponding author: Charles $\mathrm{P}$ Makoutode, Doctoral School Multidisciplinary Space Culture and Development, Faculty of Letters Arts and Human Sciences, University of Abomey Calavi, 01 BP 526, Cotonou, Benin, Tel: +229-213416749; E-mail: makoutodepatrick@yahoo.fr

Received date: Mar 28, 2017; Accepted date: Apr 10, 2017; Published date: Apr 20, 2017

Copyright: (c) 2017 Makoutode CP, et al. This is an open-access article distributed under the terms of the Creative Commons Attribution License, which permits unrestricted use, distribution, and reproduction in any medium, provided the original author and source are credited.

\begin{abstract}
Background: The economic burden of malaria for households in the municipality of Kouandé and in the control and municipality of Copargo in Benin was assessed in two cross-sectional studies before and after the implementation of Indoor Residual Spraying (IRS).

Method: This study was conducted in two phases: Just before the implementation of the IRS and one year later. The same methodological approach was strictly followed for each of the two phases. The selection of households was made by systematic random sampling from the register of patients obtained from each of the four health centers. The health center sampling frame was a list of patients who had been confirmed by Rapid Diagnostic Test (RDT) or Thick Drop (GE) and who had completed treatment for malaria no later than four weeks prior to the survey. In total, 400 and 405 households respectively were sampled and surveyed during the two phases.

Results: The pre-intervention economic indicators were significantly higher than those obtained after intervention at the urban district level (Kouandé-Centre), whereas the opposite result was observed at the level of the rural district (Guilmaro). In the control zone, regardless of the type of rounding, the pre-intervention economic indicators were significantly higher than those obtained after the intervention, except for the indirect costs for which there was no significant difference before and after the intervention. These results showed at first sight that in three out of four districts the economic indicators decreased significantly in one year, irrespective of the implementation of intervention or not. It could be inferred that the results obtained cannot be attributed to the implementation of the IRS alone. The median theoretical household income available before and after the intervention was significantly lower than the median economic cost of malaria for the household at Kouandé centre and Pabégou whereas there was no significant difference between these two parameters in Copargo centre and at Guilmaro.
\end{abstract}

Conclusion: As a general rule for these two communes, the occurrence of malaria (especially severe) would significantly influence the availability of saving at the household level.

Keywords: Malaria; Economic cost; Indoor Residual Spraying; LLIN; Benin

\section{Introduction}

Malaria is and remains a major public health and development problem. Indeed, the estimates indicate 216 million episodes of malaria in 2010 , of which $81 \%$ was reported to have occurred in the WHO African Region, with 174 million cases. The number of deaths due to malaria is estimated at 655,000 in 2010 , of which $91 \%$ is accounted for by Africa. Globally, $86 \%$ of malaria deaths occurred among children under 5 years [1].

Malaria is considered as a hindrance to the development of most countries affected by the disease because of associated DALY loss, life loss and work days. Despite the existence of prevention and treatment practices, the number of people who die from the disease each year in the world is estimated at about one million [2].
Malaria also has economic consequences for households because of the financial risk exposure. Indeed, according to the results of economic cost studies, generally the financial burden for malaria episodes (especially severe) significantly impact households' income and especially the availability of savings.

This study seeks to compare the evolution of the economic cost of malaria to the patient before and after the implementation of the IRS between urban and rural districts of the municipalities of Kouandé and Copargo in northern Benin.

The objective of this study is to assess the economic significance of malaria for households in the municipality of Kouandé and in the Control municipality of Copargo in Benin. 
Citation: Makoutodé CP, Audibert M, Massougbodji A (2017) Economic Burden of Malaria for Households in the Municipality of Kouandé and in the Control and Municipality of Copargo in Benin. Health Econ Outcome Res 3: 128.DOI: 10.4172/2471-268X.1000128

Page 2 of 9

\section{Materials and Methods}

\section{Selection and sites of the study}

The study was conducted in two municipalities, Kouandé and Copargo, in Benin. The municipality of Kouandé covers an area of $4,500 \mathrm{~km}^{2}$ and is bounded by the municipalities of Kérou (North), Tanguiéta (Northwest), Copargo, Djougou and Boukombé (South) and the urban commune of Natitingou (Southwest). The climate, SudanoGuinean, is characterized by a rainy season, from mid-April to midOctober and a dry season from mid-October to mid-April. The municipality benefits from a dense river system, consisting of a few perennial streams, several rivers and seasonal streams. Bariba constitutes the majority of the common socio-cultural group (43.6\%), followed by Bètamaribè [2] (24\%), both characterized by farmers. Following is the Fulani group (17.9\%) consisting mainly of breeders after which Yom Lokpa (7.2\%) follows. Other socio-cultural groups represent $7.2 \%$. The main religions are Islam (38.5\%), traditional religions (30.2\%) and Catholicism (14.8\%) [3].

The municipality of Copargo extends over an area of $876 \mathrm{~km}^{2}$ and is bordered by the municipalities of Natitingou and Kouandé (North), Djougou and Ouaké (South and East) and by the Republic of Togo (West). The climate, Sudano-Guinean, is characterized by a rainy season, from mid-April to mid-October and a dry season from midOctober to mid-April. Corpargo municipality is crossed and watered by several rivers. Its population is composed mostly of Yom Lokpas which represent $83 \%$ of the population and Fulani (7.2\%).

Since 2010, the Regional Institute of Public Health (IRSP) with the financial support of USAID has ensured the strengthening of epidemiological surveillance of malaria in the municipality of Kouandé.

The study on the geographical surveying of this municipality focused on the physical nature of the habitat and possession of LLINs. This study confirmed the eligibility of Kouandé municipality for IRS prior to its selection for study [4-6].

The entomological study reported that mosquitoes of the Kouandé municipality are highly sensitive to bendiocarb (1-95\%) which is the insecticide used for the IRS [7]. The mixed strategy (IRS+LLINs) was introduced into the Kouandé municipality in June 2011, prior to this date it was only LLINs strategy that existed.

The Municipality of Copargo was chosen because of its geographical position and its cultural similarity with the Kouandé municipality. The dominant religion is traditional religion (70\%), Islam (18\%) and Christianity (8\%) [4]. In the municipality of Donga department, only LLIN strategy is in use (Figure 1).

\section{Type and period of study}

This cross-sectional study was executed in two phases. The first in May 2011 (just before the IDP) and the second a year later, May 2012.

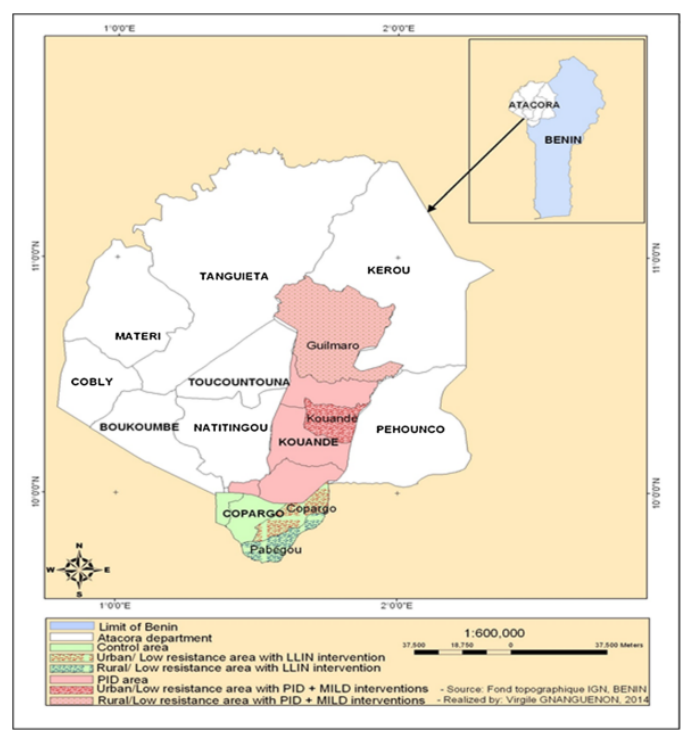

Figure 1: Characteristics of the municipalities studied.

\section{Target population}

The study population essentially comprised of patients, their caregivers and health workers.

For the main targets (patients and their caregivers), the following inclusion criteria were considered:

Patients with positive diagnostic rapid test or thick gout (DRT/TG), hospitalized or not, and agreed to participate in the study.

Companions who irrespective of their income-generating activity, have spent at least $2 / 3$ of the stay with the patient and agreed to participate in the study.

\section{Sampling and Data Collection}

The same methodological approach was observed strictly in both phases (before and after the intervention) with respect to the choice of health workers. As for the selection of households, this was achieved employing systematic random sampling from the register of patients received in each of the four health centers. The survey steps were respectively 2 for Guilmaro and Pabégou, 4 for Copargo center and 7 for Kouandé center. The health center sampling frame was a list of patients who had been confirmed by diagnostic rapid test or thick gout (DTR/TG) and who had completed treatment for malaria no later than four weeks prior to the survey. The size of the households surveyed was calculated using the SCHWARTZ formula [8] with a prevalence of $50 \%$, an accuracy of $5 \%$ and a significance level of $5 \%$.

$\mathrm{N}=384$ patients, i.e., 400 patients at the rate of 100 per selected round. 
Citation: Makoutodé CP, Audibert M, Massougbodji A (2017) Economic Burden of Malaria for Households in the Municipality of Kouandé and in the Control and Municipality of Copargo in Benin. Health Econ Outcome Res 3: 128.DOI: 10.4172/2471-268X.1000128

Page 3 of 9

The selected patients were traced in their respective communities on the basis of information from the registers and with the help of community workers. Data collection was conducted from April 20 to May 13, 2012.

Socio-economic data were collected using documents (with a scorecard) and semi-structured interviews (with questionnaire). Prior to every encounter, an informed consent form was signed or stamped by the respondent.

A total of 400 and 405 households (comprising of patients and caregivers) were sampled and interviewed in both phases respectively. Interviews were conducted with health workers as needed to supplement or confirm certain information regarding the prestation cost.

\section{Method of Calculating Costs}

\section{Estimated direct cost}

For a patient, it is composed of the cost of medical consultation (CC), the cost of microscopic examination (EC), drug cost (CM), patient cost of transport (CT), Mosquito protection (CP), cost of restoration (CR) and hospitalization costs $(\mathrm{FH})$. To calculate the total number of patients $\mathrm{M}$ and $\mathrm{m}$ of patients, the direct cost formula employed was as follows:

$\mathrm{CD}=[($ C.C + C.E. + C.M+C.T+C.P.C.R. $) \times \mathrm{M}]+\mathrm{m} \times \mathrm{FH}$

\section{Estimated indirect cost (C.I.)}

In the present study, the indirect cost was calculated specifically for severe malaria cases. Indeed, it is assumed that in the endemic zone simple malaria does not significantly influence the loss of productivity for the patient and his or her caregiver, but this loss occurs rather as soon as he is hospitalized for severe malaria. The indirect cost is the monetary estimate of the loss of productivity induced by the occurrence of severe malaria for a patient, his or her primary caregiver (who stayed with the patient for more than two-thirds of the duration of Hospitalization) and possibly his or her head of household.

Three principles guided the estimation of the indirect cost:

Severe malaria in Benin mainly concerns children ( $\leq 15$ years), pregnant women and the elderly; Children ( $\leq 15$ years) do not produce and do not contribute significantly to the household income.

The head of household in this context often does not stay in the hospital with the patient but goes about his business to ensure the availability of funds for the treatment of the patient. This does not exclude cases where he can play both roles (household head and primary caregiver) simultaneously.

In the present study, the indirect cost estimation approach consisted first of all of determining the age of the patients and their caregivers as well as the time they lost. Then we identified, based on the median incomes by Professional category for the patient, his or her primary caregiver and possibly the head of the household.

The indirect cost for a given patients calculated by the formula:

$$
\mathrm{CI}=[(\mathrm{Rm} \times \mathrm{Tm} \times \alpha)+(\operatorname{Racc} \times \mathrm{Tacc})]
$$

$\mathrm{R}$ is the median individual economic income in the occupation attributable to a given patient $(\mathrm{m})$ or caregiver/accompanying person (acc).
$\mathrm{Tm}$ is the time lost by a given patient due to the illness.

Tacc is the time lost by the primary caregiver (head of household or not) of a given patient due to the illness.

$\alpha$ is set to 1 if the patient's age is greater than 15 years and 0 if the patient's age is less than or equal to 15 years.

\section{Estimated economic cost (CE)}

For a given patient, the economic cost is the sum of the direct cost and the indirect cost.

It is given by the following formula: $\mathrm{C} \mathrm{E}=\mathrm{CD}+\mathrm{CI}$.

Estimated Theoretical Income for the Household by Episode of Malaria.

This estimate is based on the household's annual income and the number of days the patient is hospitalized. The aim here is to estimate the theoretical income of the household (what the household is supposed to have) to cope with an episode of malaria. It is given by the formula:

\section{Rthd $=\mathrm{Rm} / 365 \times \mathrm{Tm}$}

Rthd is the theoretical income available per episode of malaria.

$\mathrm{Rm}$ is the annual household income.

$\mathrm{Tm}$ is the time lost by a given patient because of his or her illness.

To minimize the influence of extreme data, the median was used to calculate the cost.

\section{Ethical considerations}

The investigator provided or read each time a fact sheet specifying the objectives of the research and the future use of the data. After this information, the persons who agreed to participate in the research read and signed the consent form before the interviews began.

\section{Analysis of data}

The economic data collected were entered in Epidata 3.1. A double entry was made to ensure the reliability of the data collected followed by data purification. The data entered in Epidata 3.1 were then transferred to STATA 11 for analysis. An analysis program under STATA 11 had been designed in accordance with the above-mentioned costing methodology. The median comparison test and more precisely the exact Fisher test were used for the comparisons.

\section{Results}

The results are presented by types of economic indicators before and after the implementation of the IRS and then the comparison of both phases. The median theoretical income was also compared to the median economic cost before and after the intervention.

\section{Characteristic of the sample}

It is a population consisting essentially of farmers ( $41 \%$ and $48 \%)$, merchants (24\% and $18 \%)$, craftsmen (21\% and $8 \%)$, housewives $(2 \%$ and $5 \% \%)$, Public servants ( $9 \%$ and $2 \%$ ) and spiritual and healers (1\%).

The highest annual median earnings observed with professions lower represented in the sample: healers/spiritual $(1,120,000$ and 
Citation: Makoutodé CP, Audibert M, Massougbodji A (2017) Economic Burden of Malaria for Households in the Municipality of Kouandé and in the Control and Municipality of Copargo in Benin. Health Econ Outcome Res 3: 128.DOI: 10.4172/2471-268X.1000128

Page 4 of 9

480,000 FCFA), teachers (780,000 and 820,000 FCFA), civil servants $(360,000$ and 900,000 FCFA) and breeders $(325,000$ and 416,500 FCFA).

\section{Evolution of economic indicators}

Tables 1-4 present the results of the comparative tests of the economic indicators at the level of the four boroughs selected for the study. Table 1 showed that, in the intervention zone, the preintervention economic indicators were significantly higher than those obtained after the urban district (Kouandé-Center) intervention, whereas the contrary was observed at the level of the rural district (Guilmaro).
Table 2 showed that in the control zone, regardless of the type of rounding, pre-intervention economic indicators were significantly higher than those obtained after the intervention, except for indirect costs for which there was no significant difference before and after surgery.

Table 4 showed that direct, indirect and economic costs were significantly higher in Pabégou than in Guilmaro prior to the implementation of the IRS. After the implementation of the IDP, the direct and economic costs for households in Guilmaro were significantly higher than those of Pabégou. However, the opposite result was observed with regards to the indirect costs for the households.

\begin{tabular}{|c|c|c|c|c|c|c|c|c|}
\hline \multirow{3}{*}{ Indicators } & \multicolumn{4}{|c|}{ Kouandé-Centre } & \multicolumn{4}{|c|}{ Guilmaro } \\
\hline & \multirow{2}{*}{$\begin{array}{l}\text { Before } \\
\text { IRS }\end{array}$} & \multirow{2}{*}{$\begin{array}{l}\text { After } \\
\text { IRS }\end{array}$} & \multirow[t]{2}{*}{$\mathbf{P}$} & \multirow[t]{2}{*}{ Interpretation } & \multirow{2}{*}{$\begin{array}{l}\text { Before } \\
\text { IRS }\end{array}$} & \multirow{2}{*}{$\begin{array}{l}\text { After } \\
\text { IRS }\end{array}$} & \multirow[t]{2}{*}{$\mathbf{P}$} & \multirow[t]{2}{*}{ Interpretation } \\
\hline & & & & & & & & \\
\hline $\begin{array}{l}\text { Median direct cost } \\
\text { simple malaria for the } \\
\text { household }\end{array}$ & 6,354 & 1,600 & $<0.001$ & $\begin{array}{l}\text { Fisher's exact unilateral test } \\
\text { reveals that the median } \\
\text { direct cost of simple malaria } \\
\text { to the household is higher } \\
\text { than that after the } \\
\text { implementation of IRS }\end{array}$ & 874.5 & 1,200 & 0.568 & $\begin{array}{l}\text { Fisher's exact unilateral } \\
\text { test reveals that the } \\
\text { median direct cost of } \\
\text { simple malaria for the } \\
\text { household is the same } \\
\text { before and after the } \\
\text { implementation of IRS }\end{array}$ \\
\hline $\begin{array}{l}\text { Median direct cost } \\
\text { severe malaria for the } \\
\text { household }\end{array}$ & 6,651 & 5,450 & 0.423 & $\begin{array}{l}\text { Fisher's exact unilateral test } \\
\text { reveals that the median } \\
\text { direct cost of severe malaria } \\
\text { for the household is the } \\
\text { same before and after the } \\
\text { implementation of IRS }\end{array}$ & 950 & 3,000 & $<0.001$ & $\begin{array}{l}\text { Fisher's exact unilateral } \\
\text { test reveals that the } \\
\text { median direct cost of } \\
\text { severe malaria to the } \\
\text { front household is lower } \\
\text { than that after the } \\
\text { implementation of IRS }\end{array}$ \\
\hline $\begin{array}{l}\text { Median indirect cost } \\
\text { simple malaria for the } \\
\text { household }\end{array}$ & 6,604 & 3,400 & 0.005 & $\begin{array}{l}\text { Fisher's exact unilateral test } \\
\text { reveals that the median } \\
\text { direct cost to the front } \\
\text { household is higher than } \\
\text { that after the implementation } \\
\text { of the IRS }\end{array}$ & 9,745 & 3,000 & $<0.001$ & $\begin{array}{l}\text { Fisher's exact unilateral } \\
\text { test reveals that the } \\
\text { median direct cost to the } \\
\text { front household is lower } \\
\text { than that after the } \\
\text { implementation of the } \\
\text { IRS }\end{array}$ \\
\hline $\begin{array}{l}\text { Median indirect cost } \\
\text { severe malaria for the } \\
\text { household }\end{array}$ & $6,027.4$ & $3,284.9$ & 0.005 & $\begin{array}{l}\text { Fisher's exact one-tailed test } \\
\text { reveals that the median } \\
\text { indirect cost to the front } \\
\text { household is higher than } \\
\text { that after the implementation } \\
\text { of the IRS }\end{array}$ & $1,622.9$ & 606.8 & $<0.001$ & $\begin{array}{l}\text { Fisher's exact one-tailed } \\
\text { test reveals that the } \\
\text { median indirect cost to } \\
\text { the front household is } \\
\text { higher than that after the } \\
\text { implementation of the } \\
\text { IRS }\end{array}$ \\
\hline $\begin{array}{l}\text { Median economic } \\
\text { cost malaria for the } \\
\text { household }\end{array}$ & 10,2429 & 5,0691 & 0.016 & $\begin{array}{l}\text { Fisher's exact unilateral test } \\
\text { reveals that the median } \\
\text { economic cost to the front } \\
\text { household is higher than } \\
\text { that after the implementation } \\
\text { of the IRS }\end{array}$ & 2,9571 & $3,606.8$ & $<0.001$ & $\begin{array}{l}\text { Fisher's exact unilateral } \\
\text { test reveals that the } \\
\text { median economic cost to } \\
\text { the front household is } \\
\text { lower than that after the } \\
\text { implementation of the } \\
\text { IRS }\end{array}$ \\
\hline $\begin{array}{lr}\text { Median duration of } \\
\text { hospitalization for } \\
\text { severe } \\
\text { (disability) }\end{array}$ & 5 & 3 & $<0.001$ & $\begin{array}{l}\text { Fisher's exact unilateral test } \\
\text { reveals that the median } \\
\text { duration of disability before } \\
\text { is significantly higher than } \\
\text { that after the implementation } \\
\text { of IRS }\end{array}$ & 2 & 2 & 1.00 & $\begin{array}{l}\text { Fisher's exact unilateral } \\
\text { test reveals that the } \\
\text { median duration of } \\
\text { disability is rot } \\
\text { significantly different } \\
\text { before and after the } \\
\text { implementation of IRS }\end{array}$ \\
\hline
\end{tabular}

Table 1: Results of the comparison test of the key economic indicators between the districts of the zone of intervention before and after the intervention. 
Citation: Makoutodé CP, Audibert M, Massougbodji A (2017) Economic Burden of Malaria for Households in the Municipality of Kouandé and in the Control and Municipality of Copargo in Benin. Health Econ Outcome Res 3: 128.DOI: 10.4172/2471-268X.1000128

Page 5 of 9

\begin{tabular}{|c|c|c|c|c|c|c|c|c|}
\hline \multirow[t]{3}{*}{ Indicators } & \multicolumn{4}{|c|}{ Copargo-Centre } & \multicolumn{4}{|l|}{ Pabégou } \\
\hline & \multirow{2}{*}{$\begin{array}{l}\text { Before } \\
\text { IRS }\end{array}$} & \multirow{2}{*}{$\begin{array}{l}\text { After } \\
\text { IRS }\end{array}$} & \multirow[t]{2}{*}{$\mathbf{P}$} & \multirow[t]{2}{*}{ Interpretation } & \multirow{2}{*}{$\begin{array}{l}\text { Before } \\
\text { IRS }\end{array}$} & \multirow{2}{*}{$\begin{array}{l}\text { After } \\
\text { IRS }\end{array}$} & \multirow[t]{2}{*}{$\mathbf{P}$} & \multirow[t]{2}{*}{ Interpretation } \\
\hline & & & & & & & & \\
\hline $\begin{array}{l}\text { Median direct cost } \\
\text { simple malaria for the } \\
\text { household }\end{array}$ & 2,182 & 1,250 & 0.003 & $\begin{array}{l}\text { Fisher's exact unilateral } \\
\text { test reveals that the } \\
\text { median direct cost of } \\
\text { simple malaria to the } \\
\text { front household is higher } \\
\text { than that after the } \\
\text { implementation of IRS }\end{array}$ & 1,122 & 750 & 0.029 & $\begin{array}{l}\text { Fisher's exact unilateral } \\
\text { test reveals that the } \\
\text { median direct cost of } \\
\text { simple malaria to the } \\
\text { front household is higher } \\
\text { than that after the } \\
\text { implementation of IRS }\end{array}$ \\
\hline $\begin{array}{l}\text { Median direct cost } \\
\text { severe malaria for the } \\
\text { household }\end{array}$ & $2,466,8$ & 1,450 & 0.019 & $\begin{array}{l}\text { Fisher's exact unilateral } \\
\text { test reveals that the } \\
\text { median direct cost of } \\
\text { severe malaria to the } \\
\text { front household is higher } \\
\text { than that after the } \\
\text { implementation of IRS }\end{array}$ & $3,631.5$ & 1,700 & $<0.001$ & $\begin{array}{l}\text { Fisher's exact unilateral } \\
\text { test reveals that the } \\
\text { median direct cost of } \\
\text { severe malaria to the } \\
\text { front household is higher } \\
\text { than that after the } \\
\text { implementation of IRS }\end{array}$ \\
\hline $\begin{array}{l}\text { Median indirect cost } \\
\text { simple malaria for the } \\
\text { household }\end{array}$ & 2,322 & 1,400 & $<0.001$ & $\begin{array}{l}\text { Fisher's exact unilateral } \\
\text { test reveals that the } \\
\text { median direct cost to the } \\
\text { front household is higher } \\
\text { than that after the } \\
\text { implementation of the } \\
\text { IRS }\end{array}$ & 3,374 & 1,400 & $<0.001$ & $\begin{array}{l}\text { Fisher's exact unilateral } \\
\text { test reveals that the } \\
\text { median direct cost to the } \\
\text { front household is higher } \\
\text { than that after the } \\
\text { implementation of the } \\
\text { IRS }\end{array}$ \\
\hline $\begin{array}{l}\text { Median indirect cost } \\
\text { severe malaria for the } \\
\text { household }\end{array}$ & $1,759.1$ & $1,095.9$ & 0,248 & $\begin{array}{l}\text { Fisher's exact unilateral } \\
\text { test reveals that the } \\
\text { median indirect cost to } \\
\text { the household is the } \\
\text { same before and after } \\
\text { the implementation of } \\
\text { the IRS }\end{array}$ & $3,544.8$ & $2,136.9$ & 0.219 & $\begin{array}{l}\text { Fisher's exact unilateral } \\
\text { test reveals that the } \\
\text { median indirect cost to } \\
\text { the household is the } \\
\text { same before and after } \\
\text { the implementation of } \\
\text { the IRS }\end{array}$ \\
\hline $\begin{array}{l}\text { Median economic cost/ } \\
\text { impact of malaria on } \\
\text { the household }\end{array}$ & $3,282.7$ & $2,283.6$ & 0.009 & $\begin{array}{l}\text { Fisher's exact unilateral } \\
\text { test reveals that the } \\
\text { median economic cost to } \\
\text { the front household is } \\
\text { higher than that after the } \\
\text { implementation of the } \\
\text { IRS }\end{array}$ & $6,529.6$ & $3,572.6$ & 0.005 & $\begin{array}{l}\text { Fisher's exact unilateral } \\
\text { test reveals that the } \\
\text { median economic cost to } \\
\text { the front household is } \\
\text { higher than that after the } \\
\text { implementation of the } \\
\text { IRS }\end{array}$ \\
\hline $\begin{array}{lr}\text { Median duration of } \\
\text { hospitalization } & \text { for } \\
\text { severe } & \text { malaria } \\
\text { (disability) } & \end{array}$ & 4 & 2 & $<0.001$ & $\begin{array}{l}\text { Fisher's exact unilateral } \\
\text { test reveals that the } \\
\text { median duration of } \\
\text { disability before is } \\
\text { significantly higher than } \\
\text { that after the } \\
\text { implementation of IRS }\end{array}$ & 2 & 2 & 1.00 & $\begin{array}{l}\text { Fisher's exact unilateral } \\
\text { test reveals that the } \\
\text { median duration of } \\
\text { disability is not } \\
\text { significantly different } \\
\text { before and after the } \\
\text { implementation of IRS }\end{array}$ \\
\hline
\end{tabular}

Table 2: Results of the comparison test of key economic indicators between districts of the control zone in the same period.

\begin{tabular}{|c|c|c|c|c|c|c|c|c|}
\hline \multirow[t]{2}{*}{ Indicators } & \multicolumn{4}{|c|}{ Before implementation of IRS } & \multicolumn{4}{|c|}{ After implementation of IRS } \\
\hline & $\begin{array}{l}\text { Kouandé } \\
\text { Centre }\end{array}$ & $\begin{array}{l}\text { Copargo- } \\
\text { Centre } \\
\text { (control) }\end{array}$ & $\mathbf{P}$ & Interpretation & $\begin{array}{l}\text { Kouandé- } \\
\text { Centre }\end{array}$ & $\begin{array}{l}\text { Copargo- } \\
\text { Centre } \\
\text { (control) }\end{array}$ & $\mathbf{P}$ & Interpretation \\
\hline $\begin{array}{l}\text { Median direct cost } \\
\text { simple malaria for } \\
\text { the household }\end{array}$ & 6,354 & 2,182 & $<0.001$ & $\begin{array}{l}\text { Fisher's exact } \\
\text { unilateral test reveals } \\
\text { that the median direct } \\
\text { cost of simple malaria } \\
\text { in Kouandé is } \\
\text { significantly higher } \\
\text { than that of Copargo }\end{array}$ & 1,600 & 1,250 & 0.789 & $\begin{array}{l}\text { Fisher's exact } \\
\text { unilateral test reveals } \\
\text { that the median direct } \\
\text { cost of simple malaria } \\
\text { in Kouandé is the } \\
\text { same as that of } \\
\text { Copargo }\end{array}$ \\
\hline
\end{tabular}


Citation: Makoutodé CP, Audibert M, Massougbodji A (2017) Economic Burden of Malaria for Households in the Municipality of Kouandé and in the Control and Municipality of Copargo in Benin. Health Econ Outcome Res 3: 128.DOI: 10.4172/2471-268X.1000128

Page 6 of 9

\begin{tabular}{|c|c|c|c|c|c|c|c|c|}
\hline $\begin{array}{l}\text { Median direct cost } \\
\text { severe malaria for } \\
\text { the household }\end{array}$ & 6,651 & $2,466.8$ & $<0.001$ & $\begin{array}{l}\text { Fisher's exact } \\
\text { unilateral test reveals } \\
\text { that the median direct } \\
\text { cost of severe malaria } \\
\text { in Kouandé is } \\
\text { significantly higher } \\
\text { than that of Copargo }\end{array}$ & 5,450 & 1,450 & $<0.001$ & $\begin{array}{l}\text { Fisher's exact } \\
\text { unilateral test reveals } \\
\text { that the median direct } \\
\text { cost of severe malaria } \\
\text { in Kouandé is } \\
\text { significantly higher } \\
\text { than that of Copargo }\end{array}$ \\
\hline $\begin{array}{l}\text { Median indirect cost } \\
\text { simple malaria for } \\
\text { the household }\end{array}$ & 6,604 & 2,322 & $<0.001$ & $\begin{array}{lr}\text { Fisher's exact } \\
\text { unilateral test reveals } \\
\text { that the median direct } \\
\text { cost of malaria in } \\
\text { Kouande } \\
\text { significantly higher } \\
\text { than that of Copargo }\end{array}$ & 3,400 & 1,400 & $<0.001$ & $\begin{array}{l}\text { Fisher's exact } \\
\text { unilateral test reveals } \\
\text { that the median direct } \\
\text { cost of malaria in } \\
\text { Kouande } \\
\text { significantly higher } \\
\text { than that of Copargo }\end{array}$ \\
\hline $\begin{array}{l}\text { Median indirect cost } \\
\text { severe malaria for } \\
\text { the household }\end{array}$ & $6,027.4$ & $1,759.1$ & 0.001 & $\begin{array}{l}\text { Fisher's exact } \\
\text { unilateral test reveals } \\
\text { that the median } \\
\text { indirect cost of } \\
\text { malaria in Kouandé is } \\
\text { significantly higher } \\
\text { than that of Copargo }\end{array}$ & $3,284.9$ & $1,095.9$ & 0.173 & $\begin{array}{l}\text { Fisher's exact } \\
\text { unilateral test reveals } \\
\text { that the median } \\
\text { indirect cost of severe } \\
\text { malaria in Kouandé is } \\
\text { the same as that of } \\
\text { Copargo }\end{array}$ \\
\hline $\begin{array}{l}\text { Median economic } \\
\text { cost malaria for the } \\
\text { household }\end{array}$ & $10,242.9$ & $3,282, .7$ & $<0.001$ & $\begin{array}{l}\text { Fisher's exact } \\
\text { unilateral test reveals } \\
\text { that the median } \\
\text { economic cost of } \\
\text { malaria in Kouandé is } \\
\text { significantly higher } \\
\text { than that of Copargo }\end{array}$ & $5,069.1$ & $2,283.6$ & $<0.001$ & $\begin{array}{l}\text { Fisher's exact } \\
\text { unilateral test reveals } \\
\text { that the median } \\
\text { economic cost of } \\
\text { malaria in Kouandé is } \\
\text { significantly higher } \\
\text { than that of Copargo }\end{array}$ \\
\hline $\begin{array}{lr}\text { Median } & \text { duration of } \\
\text { hospitalization } & \text { for } \\
\text { severe } & \text { malaria } \\
\text { (disability) } & \end{array}$ & 5 & 4 & $<0.001$ & $\begin{array}{l}\text { Fisher's exact } \\
\text { unilateral test reveals } \\
\text { that the median } \\
\text { duration of disability } \\
\text { in Kouandé is not } \\
\text { significantly different } \\
\text { from that of Copargo }\end{array}$ & 3 & 2 & 0.009 & $\begin{array}{l}\text { Fisher's exact } \\
\text { unilateral test reveals } \\
\text { that the median } \\
\text { duration of disability in } \\
\text { Kouande is not } \\
\text { significantly different } \\
\text { from that of Copargo }\end{array}$ \\
\hline
\end{tabular}

Table 3: Results of the comparison test of key economic indicators between Kouandé centre and Copargo centre before and after the implementation of the IRS.

\begin{tabular}{|c|c|c|c|c|c|c|c|c|}
\hline \multirow[t]{2}{*}{ Indicators } & \multicolumn{4}{|c|}{ Before implementation of IRS } & \multicolumn{4}{|c|}{ After implementation of IRS } \\
\hline & Guilmaro & $\begin{array}{l}\text { Pabégou } \\
\text { (control) }\end{array}$ & $\mathbf{P}$ & Interpretation & Guilmaro & $\begin{array}{l}\text { Pabégou } \\
\text { (control) }\end{array}$ & $\mathbf{P}$ & Interpretation \\
\hline $\begin{array}{l}\text { Median direct cost } \\
\text { simple malaria for the } \\
\text { household }\end{array}$ & 874.5 & 1,122 & 0.010 & $\begin{array}{l}\text { Fisher's exact } \\
\text { unilateral test reveals } \\
\text { that the median direct } \\
\text { cost of simple malaria } \\
\text { to Pabégou is } \\
\text { significantly higher } \\
\text { than that of Guilmaro }\end{array}$ & 1,200 & 780 & 0.009 & $\begin{array}{l}\text { Fisher's exact } \\
\text { unilateral test reveals } \\
\text { that the median direct } \\
\text { cost of simple malaria } \\
\text { in Guilmaro is } \\
\text { significantly higher } \\
\text { than that of Pabégou }\end{array}$ \\
\hline $\begin{array}{l}\text { Median direct cost } \\
\text { severe malaria for } \\
\text { the household }\end{array}$ & 950 & $3,631.5$ & $<0.001$ & $\begin{array}{l}\text { Fisher's exact } \\
\text { unilateral test reveals } \\
\text { that the median direct } \\
\text { cost of severe malaria } \\
\text { to Pabégou is }\end{array}$ & 3,000 & 1,700 & 0.273 & $\begin{array}{l}\text { Fisher's exact } \\
\text { unilateral test reveals } \\
\text { that the median direct } \\
\text { cost of severe malaria } \\
\text { at Guilmaro is the }\end{array}$ \\
\hline
\end{tabular}


Citation: Makoutodé CP, Audibert M, Massougbodji A (2017) Economic Burden of Malaria for Households in the Municipality of Kouandé and in the Control and Municipality of Copargo in Benin. Health Econ Outcome Res 3: 128.DOI: 10.4172/2471-268X.1000128

Page 7 of 9

\begin{tabular}{|c|c|c|c|c|c|c|c|c|}
\hline & & & & $\begin{array}{l}\text { significantly higher } \\
\text { than that of Guilmaro }\end{array}$ & & & & $\begin{array}{l}\text { same as that of } \\
\text { Pabégou }\end{array}$ \\
\hline $\begin{array}{l}\text { Median indirect cost } \\
\text { simple malaria for the } \\
\text { household }\end{array}$ & 974.5 & 3,374 & $<0.001$ & $\begin{array}{l}\text { Fisher's exact one- } \\
\text { tailed test reveals that } \\
\text { the median direct cost } \\
\text { of malaria for the } \\
\text { household } \\
\text { Pabégou in } \\
\text { significantly higher } \\
\text { than that of Guilmaro }\end{array}$ & 3,000 & 1,400 & $<0.001$ & $\begin{array}{l}\text { Fisher's exact } \\
\text { unilateral test reveals } \\
\text { that the median direct } \\
\text { cost of malaria for the } \\
\text { household in Guilmaro } \\
\text { is significantly higher } \\
\text { than that of Pabégou }\end{array}$ \\
\hline $\begin{array}{l}\text { Median indirect cost } \\
\text { severe malaria for } \\
\text { the household }\end{array}$ & $1,622.9$ & $3,544.8$ & $<0.001$ & $\begin{array}{l}\text { Fisher's exact } \\
\text { unilateral test reveals } \\
\text { that the median } \\
\text { indirect cost of } \\
\text { malaria to Pabégou is } \\
\text { significantly higher } \\
\text { than that of Guilmaro }\end{array}$ & 6,068 & $2,136.9$ & $<0.001$ & $\begin{array}{l}\text { Fisher's exact } \\
\text { unilateral test reveals } \\
\text { that the median } \\
\text { indirect cost of malaria } \\
\text { to Pabégou is } \\
\text { significantly higher } \\
\text { than that of Guilmaro }\end{array}$ \\
\hline $\begin{array}{l}\text { Median economic } \\
\text { cost malaria for the } \\
\text { household }\end{array}$ & $2,957.1$ & $6,529.6$ & $<0.001$ & $\begin{array}{l}\text { Fisher's exact } \\
\text { unilateral test reveals } \\
\text { that the median } \\
\text { economic cost of } \\
\text { malaria in Pabégou is } \\
\text { significantly higher } \\
\text { than in Guilmaro }\end{array}$ & $3,606.8$ & $3,572.6$ & 0.032 & $\begin{array}{l}\text { Fisher's exact } \\
\text { unilateral test reveals } \\
\text { that the median } \\
\text { economic cost of } \\
\text { malaria in Pabégou is } \\
\text { significantly lower than } \\
\text { in Guilmaro }\end{array}$ \\
\hline $\begin{array}{l}\text { Median duration of } \\
\text { hospitalization for } \\
\text { severe malaria } \\
\text { (disability) }\end{array}$ & 2 & 2 & 0.628 & $\begin{array}{l}\text { Fisher's exact } \\
\text { unilateral test reveals } \\
\text { that the duration of } \\
\text { disability at Kouandé } \\
\text { is not significantly } \\
\text { different from that of } \\
\text { Copargo }\end{array}$ & 2 & 2 & $<0.001$ & $\begin{array}{l}\text { Fisher's exact one- } \\
\text { tailed test revealed that } \\
\text { the duration of } \\
\text { disability at Pabégou is } \\
\text { significantly higher } \\
\text { than that of Guilmaro }\end{array}$ \\
\hline
\end{tabular}

Table 4: Results of the comparison test of key economic indicators between Guilmaro and Pabégou before and after the intervention.

\begin{tabular}{|c|c|c|c|c|c|c|c|c|}
\hline \multirow[b]{2}{*}{ Boroughs } & \multicolumn{4}{|c|}{ Before implementation of IRS } & \multicolumn{4}{|c|}{ After implementation of IRS } \\
\hline & $\begin{array}{l}\text { Median } \\
\text { theoretical } \\
\text { Income }\end{array}$ & $\begin{array}{l}\text { Median Cost } \\
\text { Economic }\end{array}$ & $\mathbf{P}$ & Interpretation & $\begin{array}{l}\text { Median } \\
\text { theoretical } \\
\text { Income }\end{array}$ & $\begin{array}{l}\text { Median } \\
\text { Economic } \\
\text { Cost }\end{array}$ & $\mathbf{P}$ & Interpretation \\
\hline $\begin{array}{l}\text { Kouandé- } \\
\text { Centre }\end{array}$ & $7,298.6$ & $10,242.9$ & $<0.0001$ & $\begin{array}{l}\text { The theoretical income is } \\
\text { significantly lower than the } \\
\text { economic cost }\end{array}$ & $3,796.5$ & $5,069.1$ & 0.001 & $\begin{array}{l}\text { The theoretical income is } \\
\text { significantly lower than } \\
\text { the economic cost }\end{array}$ \\
\hline Guilmaro & $3,299.7$ & $2,957.1$ & 0.2732 & $\begin{array}{l}\text { No significant difference } \\
\text { between the theoretical } \\
\text { income and the economic } \\
\text { cost }\end{array}$ & $1,428.8$ & $3,606.8$ & 0.002 & $\begin{array}{l}\text { The theoretical income is } \\
\text { significantly lower than } \\
\text { the economic cost }\end{array}$ \\
\hline $\begin{array}{l}\text { Copargo- } \\
\text { Centre }\end{array}$ & $4,308.9$ & $3,282.7$ & 0.7326 & $\begin{array}{l}\text { No significant difference } \\
\text { between the theoretical } \\
\text { income and the economic } \\
\text { cost }\end{array}$ & $2,213.7$ & $2,283.6$ & 0.534 & $\begin{array}{l}\text { No significant difference } \\
\text { between the theoretical } \\
\text { income and the } \\
\text { economic cost }\end{array}$ \\
\hline Pabégou & $4,580.4$ & $6,529.6$ & $<0.0001$ & $\begin{array}{l}\text { The theoretical income is } \\
\text { significantly lower than the } \\
\text { economic cost }\end{array}$ & $2,579.4$ & $3,572.6$ & 0.568 & $\begin{array}{l}\text { No significant difference } \\
\text { between the theoretical } \\
\text { income and the } \\
\text { economic cost }\end{array}$ \\
\hline
\end{tabular}

Table 5: Synthesis of Median Theoretical Income Comparison and Median Economic Cost of Malaria Care before and After Implementation of IRS. 


\section{Evolution of median theoretical income and median economic cost}

As shown in Table 5, the median theoretical household disposable income (before and after the intervention) was significantly lower than the median economic cost of malaria for the household in KouandéCentre and Pabégou. Whereas there was no significant difference between these two parameters at Copargo-Centre and Guilmaro.

\section{Discussion}

Discussion of the results will focus on the limitations of the study and on the evolution of economic indicators before and after the intervention.

\section{Limitations of the Study}

The main limitation of this study is due to basing of the cost calculation on the narrative of the patient and his/her primary caregiver in relation to the experience of the disease. To this end information or memory biases could influence the quality of the results. However, these biases could be minimized during data collection. It was also observed the files of the patients selected by systematic printing were confronted with the statements of the respondents and where the differences in the answers were important. The interviewer returned to see the respondent to refine the answers and correct or justify the discrepancy.

\section{Evolution of Economic Indicators before and after the Intervention}

This study showed the intervention zone. The economic indicators before Intervention were significantly higher than those obtained after the intervention at the urban district level (kouandé centre). Whereas the opposite result was observed at the level of the rural district (Guilmaro). Similarly in the control zone. Regardless of the type of borough. The economic indicators before intervention were significantly higher than those obtained after the intervention. Except for the indirect costs for which no significant difference was noted before and after the intervention.

At first glance. it can be inferred that the results obtained cannot be attributed to the implementation of the IRS alone. The prevention and management of malaria activities executed by the National Malaria Control Program (NMCP) and partners could also have influenced the evolution of economic indicators in the two municipalities. These results would confirm the hypothesis that "the variation of economic indicators in the intervention zone also depend on other factors besides intra-residential spraying." Indeed. if in both the intervention zone and the control zone it was observed that the economic indicators before intervention were significantly higher than those after the intervention. it could have been assumed that there may have been a significant reduction in costs both in the intervention zone and in the control area. Since in the control zone we have the same interventions in malaria control as those in the selected area of intervention (except the IRS). The changes observed in the control zone show that there are confounding factors which make it impossible to attribute the changes in the area of intervention to the IRS alone.

On the other hand, before and after intervention. The median theoretical household income was significantly lower than the median economic cost of malaria for the household in Kouandé centre and
Pabégou. However, there was no significant difference between these two parameters at Copargo centre and at Guilmaro.

Several factors can influence household income (annuities. donations. sale of goods. wages. etc.) over time and this varies from one household to another. More, so as observed in this study. The calculated theoretical income is only an estimate because income is not uniformly distributed among households.

Although the results of this simulation remain theoretical. It appears that, as a general rule for these two municipalities. The economic cost of managing an episode of malaria (especially severe) would have a significant impact on income and savings at the household level.

Similar results were obtained by Masha F. Som. James RG Butler. Farshid Vahid. Joseph D. Njau. S. Patrick Kachur and Salim Abdulla in their study titled "The Economic Burden of Malaria in Rural Tanzania: Economic and seasonal "published in 2007. This study of contrary to ours was carried out during the dry and rainy season and the households were classified into quintiles ranging from the poorest to the poorest. The study found that expenditures due to malaria illness were significantly higher during the dry season than in the rainy season. Moreover, the poorest households bear a heavier economic burden of malaria compared to their consumption than the wealthiest households. These households are particularly vulnerable to malaria in the rainy season: When malaria prevalence is highest while liquidity is lower. These authors conclude that alternative strategies to help households cope with seasonal liquidity problems: Including insurance should be explored [9].

\section{Conclusion}

This study assessed the evolution of the economic cost of managing malaria for the household before and after the implementation of the IRS in the municipality of Kouandé and in the control municipality of Copargo in Benin. The economic cost of taking care of an episode of malaria before the implementation of the IRS significantly dropped in Kouandé centre whereas it significantly increased in Guilmaro in the same period. Similarly, in the control area: The economic cost of managing a malaria episode before the implementation of IRS declined significantly in Copargo centre and Pabégou during the same period. The study also highlighted that: As a general rule for these two municipalities; the economic cost of managing an episode of malaria (especially severe) would have a significant influence on income; and in particular, the availability of savings at the household level.

Further studies should be carried out to identify confounding factors and highlight the comparative gains or advantages of this strategy.

\section{References}

1. http://who.int/malaria/publications/world_malaria_report_2012/ wmr2012_summary_fr.pdf

2. Russel S (2004) The economic burden of illness for households in developing countries: a review ofs studies focusing on malaria. Tuberculosis and human immunodeficiency virus/acquired immunodeficiency syndrome. Am J Trop Med Hyg 71: 147-155

3. Start-up Support Program for the Communes, Cabinet Afrique Conseil (2006) Monograph of the commune of Kouandé in Benin p: 50.

4. Start-up Program for Municipalities, Cabinet Afrique Conseil (2006) Monograph of the commune of Copargo in Benin p: 70.

5. Nséka Vita T (2006) Study of the geographical recognition of the department of Atacora. Study Report. Cotonou. 
Citation: Makoutodé CP, Audibert M, Massougbodji A (2017) Economic Burden of Malaria for Households in the Municipality of Kouandé and in the Control and Municipality of Copargo in Benin. Health Econ Outcome Res 3: 128.DOI: 10.4172/2471-268X.1000128

Page 9 of 9

6. Akogbéto M (2011) Entomological database in preparation for the implementation of Indoor Residual Spraying (IRS) in the department of Atacora. Final Report. Cotonou.

7. (2004) National Institute of Statistics and Economic Analysis: RGPH. Cotonou.
8. Schwartz D (1996) Statistical methods for physicians and biologists (4th edn.). Medecine-Sciences Flammarion.

9. Somi MF, Butler JRG, Vahid F, Njau JD, Patrick SK (2007) Economic burden of malaria in rural Tanzania: variations by socioeconomic status and season. Trop Med Int Health 12: 1139-1147. 